\title{
ACCIDENT RISK IDENTIFICATION AND ITS IMPACT ANALYSES FOR STRATEGIC CONSTRUCTION SAFETY MANAGEMENT
}

\author{
Seokho CHI ${ }^{\mathrm{a}}$, Sangwon $\mathrm{HAN}^{\mathrm{b}}$, Dae Young $\mathrm{KIM}^{\mathrm{c}}$, Yoonjung SHIN ${ }^{\mathrm{a}}$ \\ ${ }^{a}$ Department of Civil and Environmental Engineering, Seoul National University, \\ Gwanak-ro 559, Gwanak-ku, 151-744 Seoul, Korea \\ ${ }^{b}$ Department of Architectural Engineering, University of Seoul, Seoul, Korea \\ ${ }^{c}$ Department of Architectural Engineering, Dong-Eui University, Busan, Korea
}

Received 17 Sep 2012; accepted 14 Nov 2012

\begin{abstract}
The study presented in this paper reviewed 9,358 accidents which occurred in the U.S. construction industry between 2002 and 2011, in order to understand the relationships between the risk factors and injury severity (e.g. fatalities, hospitalized injuries, or non-hospitalized injuries) and to develop a strategic prevention plan to reduce the likelihood of fatalities where an accident is unavoidable. The study specifically aims to: (1) verify the relationships among risk factors, accident types, and injury severity; (2) determine significant risk factors associated with each accident type that are highly correlated to injury severity; and (3) analyse the impact of the identified key factors on accident and fatality occurrence. The analysis results explained that safety managers' roles are critical to reducing human-related risks - particularly misjudgement of hazardous situations - through safety training and education, appropriate use of safety devices and proper safety inspection. However, for environment-related factors, the dominant risk factors were different depending on the different accident types. The outcomes of this study will assist safety managers to understand the nature of construction accidents and plan for strategic risk mitigation by prioritizing high frequency risk factors to effectively control accident occurrence and manage the likelihood of fatal injuries on construction sites.
\end{abstract}

Keywords: construction accident, injury severity, construction fatalities, construction safety, risk mitigation.

\section{Introduction}

The Center for Construction Research and Training (2008) reported that there were a total of 1,243 fatal injuries, costing \$US5.2 billion which occurred in the U.S. construction industry in 2005. This equates to an average of five workers dying every working day on a construction site. To prevent injuries and save the lives of construction workers there has been considerable research effort into identifying the root causes of construction accidents and proposing risk mitigation strategies (Hinze et al. 1998; Sawacha et al. 1999; Suraji et al. 2001; Haslam et al. 2005; Mitropoulos et al. 2009; Cheng et al. 2010).

Although such risk identification and mitigation efforts have contributed to the improvement of workplace safety, accidents still occur because of the dynamic, complex and unpredictable nature of construction sites and operations (Loosemore 1999). The primary purpose of this paper is to discuss how different risk factors associated with a different type of accident impact on injury severity (fatalities, hospitalized injuries or non-hospitalized injuries) in dynamic and complex construction environments.
The study specifically aims to: (1) verify the relationships among risk factors, accident types, and injury severity; (2) determine significant risk factors associated with each accident type that are highly correlated to injury severity; and (3) analyse the impact of the identified key factors on accident and fatality occurrence. The study reviewed 9,358 accidents which occurred in the U.S. construction industry between 2002 and 2011. The large number of accident samples supported reliable empirical and statistical analyses. The research outcomes will assist safety managers to understand which risk factors they need to control in order to avoid a certain type of accident or at least reduce the likelihood of fatality on a construction site.

This paper is organized into five sections. Following this introduction, Section 1 discusses literature review findings that support research objectives. Section 2 describes the dataset used for the analysis and the conceptual data analysis processes. Section 3 discusses the research findings and the final section concludes the article with the benefits and poses future research challenges.

Corresponding author: Seokho Chi

E-mail:shchi@snu.ac.kr 


\section{Literature review}

There have been significant research studies to understand the root causes of construction accidents. Hinze et al. (1998) emphasized that the first step for accident prevention was the understanding of risk factors contributing to accidents, analysing the distribution of four major fatalities including falls, struck-by, electrical shock and caught in/or between accidents and their risk sources. For the analysis they obtained accident data for two different time periods (1985-1989 and 1994-1995) from the U.S. Occupational Safety and Health Administration (OSHA). Sawacha et al. (1999) investigated factors affecting safety on construction sites in the United Kingdom (UK) and grouped them into seven risk categories including: historical, economical, psychological, technical, procedural, organizational, and environmental factors. They then determined the significant risk factors such as operator's job experience, safety incentives, and safety supervision through statistical analyses, which could control jobsite safe management performance. Cheng et al. (2010) explored accident risk factors for small construction enterprises in Taiwan and indicated that accidents tended to occur during the worker's first working day, specifically when a company had a poor safety management culture or when personal protective equipment (PPE) or safety devices were inappropriately used. Similarly, Suraji et al. (2001), Haslam et al. (2005), and Mitropoulos et al. (2009) investigated contributing factors in construction accidents and developed causation models of construction accidents considering work task characteristics, material and equipment factors, working environmental factors, work behaviour and human factors, and organizational factors. Their models contributed in assisting safety managers to prepare safer working environments and to break the chain of accident causation.

Other researchers more thoroughly analysed the safety characteristics of an individual accident type. Huang and Hinze (2003) and Chi et al. (2005) analysed the accident patterns and prevention strategies of falling accidents in the construction industry. They identified that fatal occupational falls on a construction site were closely associated with significant onsite risk factors including a lack of scaffolding compliance, inappropriate protection by guiderails or safety nets, improper use of PPE, defective tools or equipment, poor work practices and bodily actions, and misjudgement of hazardous situations. Hinze et al. (2005) similarly investigated the nature of struck-by accidents and reviewed the frequency of cases by age, materials or equipment involved in the accident, and the human or environmental factors involved. They indicated that workers were primarily struck by equipment, private vehicles, falling materials, vertically hoisted materials, horizontally transported materials and trench cave-ins when involved in risky working conditions. Chi et al. (2009) analysed electrical fatalities and divided accidents into five accident patterns: direct worker contact with an electrical powerline, boomed vehicle contact with a powerline, conductive equipment contact with a powerline, direct worker contact with energized equipment, and improperly installed or defective equipment. They then identified that failure to use safety protection devices, the improper use of PPE, failure to maintain safety distances, and poor operational practices were the major sources contributing to accidents involving electric shock.

Although these risk identification and mitigation efforts have contributed to the improvement of workplace safety, accidents still occur because of the dynamic, complex and unpredictable nature of construction sites and operations (Loosemore 1999). Additionally, there is currently a distinct lack of studies that discuss how different risk factors associated with a different type of accident impact on injury severity, which may support developing strategic safety management and injury mitigation plans. Thus, it is important to understand the relationship between risk factors and injury severity, prioritize these factors to effectively control injury occurrence, and develop a strategic prevention plan to reduce the likelihood of a fatality when an accident is unavoidable.

\section{Data analysis}

\subsection{Data description}

The authors obtained information on 9,358 accidents which occurred in the U.S. construction industry over the 10 years between 2002 and 2011 from OSHA, which requires accident information to be recorded and maintained. The dataset comprised 3,124 fatalities (33.4\%), 5,210 hospitalized injuries $(55.7 \%)$ and 1,024 nonhospitalized injuries $(10.9 \%)$, comprising the following accident types: 3,944 falls from an elevation, 2,156 struck-by, 934 caught in/or between, 567 electrical shock, 253 struck-against, 214 inhalation, 168 Card-Vasc (Cardiothoracic and Vascular) or respiratory failure, 166 falls at the same level, and 956 'others'. The original dataset included several low-frequency accident types having 100 or less observations but these were combined with the 'others' category for more reliable statistical analysis. Table 1 summarizes the frequency of each accident type and its injury distribution.

In the OSHA accident reports, the victims included construction inspectors, architects, surveyors, supervisors, masons, tile setters, carpet installers, carpenters, drywall installers, electricians, painters, plasterers, plumbers, concrete finishers, glaziers, insulation workers, roofers, duct installers, structural metal workers, earth drillers, construction trade workers, welders and cutters, crane and tower crane operators, heavy machinery operators and other general construction workers. Additionally, OSHA classifies risk factors associated with accidents into two different groups: humanrelated and environment-related. The human factors are considered when the causes of accidents are attributed to the failure of prompt action by a construction worker. The environmental factors are involved when task-related or working condition-related factors are the major causes of accidents. OSHA first determined 20 human risk fac- 
Table 1. Frequency of each accident type and its injury distribution

\begin{tabular}{|c|c|c|c|c|c|c|c|c|c|}
\hline & TYPE OF EVENT & Frequency & Percent & Fatality & Percent & Hospitalized & Percent & $\begin{array}{c}\text { Non- } \\
\text { Hospitalized }\end{array}$ & Percent \\
\hline 1 & Falls from an elevation & 3,944 & $42.15 \%$ & 1,114 & $28.25 \%$ & 2,509 & $63.62 \%$ & 321 & $8.14 \%$ \\
\hline 2 & Struck-by & 2,156 & $23.04 \%$ & 746 & $34.60 \%$ & 1,130 & $52.41 \%$ & 280 & $12.99 \%$ \\
\hline 3 & Caught in/or between & 934 & $9.98 \%$ & 326 & $34.90 \%$ & 458 & $49.04 \%$ & 150 & $16.06 \%$ \\
\hline 4 & Electrical shock & 567 & $6.06 \%$ & 368 & $64.90 \%$ & 161 & $28.40 \%$ & 38 & $6.70 \%$ \\
\hline 5 & Struck-against & 253 & $2.70 \%$ & 68 & $26.88 \%$ & 142 & $56.13 \%$ & 43 & $17.00 \%$ \\
\hline 5 & Inhalation & 214 & $2.29 \%$ & 67 & $31.31 \%$ & 98 & $45.79 \%$ & 49 & $22.90 \%$ \\
\hline 6 & $\begin{array}{l}\text { CARD-VASC/ } \\
\text { Respiratory failure }\end{array}$ & 168 & $1.80 \%$ & 162 & $96.43 \%$ & 6 & $3.57 \%$ & 0 & $0.00 \%$ \\
\hline 7 & Falls at the same level & 166 & $1.77 \%$ & 27 & $16.27 \%$ & 123 & $74.10 \%$ & 16 & $9.64 \%$ \\
\hline 8 & Others & 956 & $10.22 \%$ & 246 & $25.73 \%$ & 583 & $60.98 \%$ & 127 & $13.28 \%$ \\
\hline & TOTAL & 9,358 & $100.00 \%$ & 3,124 & & 5,210 & & 1,024 & \\
\hline
\end{tabular}

tor categories for their fatality investigations: (1) misjudgement of hazardous situations; (2) no PPE used; (3) no appropriate protective clothing; (4) malfunction of procedure for securing operation or warning of hazardous situation; (5) distracting actions by others; (6) equipment in use not appropriate for operation or process; (7) malfunction of neuro-muscular system; (8) malfunction of perception system with respect to task environment; (9) safety devices removed or inoperative; (10) operational position not appropriate for task; (11) procedure for handling materials not appropriate for task; (12) defective equipment knowingly used; (13) malfunction of lock-out or tag-out procedure; (14) insufficient or lack of housekeeping program; (15) insufficient or lack of exposure or biological monitoring; (16) insufficient or lack of engineering controls; (17) insufficient or lack of written work practices program;(18) insufficient or lack of respiratory protection; (19) insufficient or lack of protection work clothing and equipment; and (20) 'other'.

OSHA also defined 18 environmental categories for the investigation: (1) pinch point action; (2) catch point/puncture action; (3) shear point action; (4) squeeze point action; (5) flying object action; (6) overhead moving and/or falling object action; (7) gas/vapor/mist/fume/ smoke/dust condition; (8) materials handling equipment/method; (9) chemical action/reaction exposure; (10) flammable liquid/solid exposure; (11) temperature above or below tolerance level; (12) radiation condition; (13) working surface/facility layout condition, (14) illumination; (15) overpressure/underpressure condition; (16) sound level; (17) weather/earthquake, etc.; and (18) 'other'.

Each observation frequency was counted by the authors by using Microsoft Excel functions and its percentage of the total accidents was measured. The frequency belonging to each injury category - fatality, hospitalized or non-hospitalized - was also measured and explained. Table 2 summarizes the category information, the observations and their injury distribution. As shown in the table, the OSHA reports analyse accidents from both human-related and environment-related perspectives.

\subsection{Analysis structure and data processing}

Figure 1 illustrates the conceptual data analysis structure. Most accident causation studies including Heinrich's domino theory (1936) and Petersen's accident/incident model (1980) explained that accidents lead to injuries and that these accidents are caused when a worker commits unsafe acts and there are direct mechanical or physical hazards related to the work; unsafe worker behaviour becomes the major root cause of construction accidents when combined with unsafe working conditions. By considering this fundamental risk-accident-injury relationship, the research first verified the relationships among the different risk factors in Table 2, accident types, and injury severity through statistical analyses (\#1 in Fig. 1).

In this study, the Chi-square analysis, developed by Karl Pearson (1900), was conducted through the use of SPSS statistical software to analyse correlations among risks, accident types and injury severity. The Chi-square is calculated by comparing observed and expected frequencies. The expected frequencies are asserted by the null hypothesis that there is no relationship between two variables being examined. A $p$-value is then estimated by comparing the Chi-square value to the pre-determined Chi-square distribution. The number of degrees of freedom, calculated by considering the given matrix size, determines how the Chi-square statistic is distributed. Where expected frequencies were less than five, Fisher's exact test (Fisher 1954; Agresti 1992) was implemented as an alternative for the correlation analysis. Fisher's exact test uses the same null hypothesis: two variables are independent of each other. Let us suppose that two variables $X$ (misjudgement of hazardous situation) and $Y$ (injury severity) have $m$ (yes or no) and $n$ (fatality or non-fatality) observations respectively (this example was simplified for the explanation purpose). An $m \times n(2 \times 2)$ matrix can be formed, in which the entries $a_{i j}$ represent the frequency of observations; $i$ increases by $m$ and $j$ increases by $n$. For instance, if the frequency of fatality by misjudgement (the first row and the first column in Table 3 ) is 5 , then $a_{11}=5$. 
Table 2. Environmental and human factors and their frequency and injury distribution

\begin{tabular}{|c|c|c|c|c|c|c|c|c|c|}
\hline & $\begin{array}{l}\text { NVIRONMENTAL } \\
\text { FACTOR }\end{array}$ & Frequency & Percent & Fatality & Percent & Hospitalized & Percent & $\begin{array}{c}\text { Non- } \\
\text { Hospitalized }\end{array}$ & Percent \\
\hline EN1 & $\begin{array}{l}\text { PINCH POINT } \\
\text { ACTION }\end{array}$ & 260 & $2.78 \%$ & 56 & $21.54 \%$ & 135 & $51.92 \%$ & 69 & $26.54 \%$ \\
\hline EN2 & $\begin{array}{l}\text { CATCH POINT/ } \\
\text { PUNCTURE ACTION }\end{array}$ & 216 & $2.31 \%$ & 24 & $11.11 \%$ & 144 & $66.67 \%$ & 48 & $22.22 \%$ \\
\hline EN3 & $\begin{array}{l}\text { SHEAR POINT } \\
\text { ACTION }\end{array}$ & 222 & $2.37 \%$ & 8 & $3.60 \%$ & 167 & $75.23 \%$ & 47 & $21.17 \%$ \\
\hline EN4 & $\begin{array}{l}\text { SQUEEZE POINT } \\
\text { ACTION }\end{array}$ & 309 & $3.30 \%$ & 125 & $40.45 \%$ & 149 & $48.22 \%$ & 35 & $11.33 \%$ \\
\hline EN5 & $\begin{array}{l}\text { FLYING OBJECT } \\
\text { ACTION }\end{array}$ & 388 & $4.15 \%$ & 64 & $16.49 \%$ & 262 & $67.53 \%$ & 62 & $15.98 \%$ \\
\hline EN6 & $\begin{array}{l}\text { OVERHEAD } \\
\text { MOVING/FALLING } \\
\text { OBJ AC }\end{array}$ & 954 & $10.19 \%$ & 333 & $34.91 \%$ & 507 & $53.14 \%$ & 114 & $11.95 \%$ \\
\hline EN7 & $\begin{array}{l}\text { GAS/VAPOR/MIST/ } \\
\text { FUME/ SMOKE/ } \\
\text { DUST }\end{array}$ & 297 & $3.17 \%$ & 84 & $28.28 \%$ & 157 & $52.86 \%$ & 56 & $18.86 \%$ \\
\hline EN8 & $\begin{array}{l}\text { MATERIALS } \\
\text { HANDLG EQUIP./ } \\
\text { METHOD }\end{array}$ & 744 & $7.95 \%$ & 304 & $40.86 \%$ & 376 & $50.54 \%$ & 64 & $8.60 \%$ \\
\hline EN9 & $\begin{array}{l}\text { CHEMICAL } \\
\text { ACTION/REACTION } \\
\text { EXPOS }\end{array}$ & 47 & $0.50 \%$ & 16 & $34.04 \%$ & 24 & $51.06 \%$ & 7 & $14.89 \%$ \\
\hline EN10 & $\begin{array}{l}\text { FLAMMABLE LIQ/ } \\
\text { SOLID EXPOSURE }\end{array}$ & 112 & $1.20 \%$ & 31 & $27.68 \%$ & 76 & $67.86 \%$ & 5 & $4.46 \%$ \\
\hline EN11 & $\begin{array}{l}\text { TEMPERATURE +/- } \\
\text { TOLERANCE LEV. }\end{array}$ & 123 & $1.31 \%$ & 35 & $28.46 \%$ & 67 & $54.47 \%$ & 21 & $17.07 \%$ \\
\hline EN12 & $\begin{array}{l}\text { RADIATION } \\
\text { CONDITION }\end{array}$ & 12 & $0.13 \%$ & 3 & $25.00 \%$ & 8 & $66.67 \%$ & 1 & $8.33 \%$ \\
\hline EN13 & $\begin{array}{l}\text { WORK- SURFACE/ } \\
\text { FACIL-LAYOUT } \\
\text { COND }\end{array}$ & 2,443 & $26.11 \%$ & 789 & $32.30 \%$ & 1,458 & $59.68 \%$ & 196 & $8.02 \%$ \\
\hline EN14 & ILLUMINATION & 27 & $0.29 \%$ & 18 & $66.67 \%$ & 9 & $33.33 \%$ & 0 & $0.00 \%$ \\
\hline EN15 & $\begin{array}{l}\text { OVERPRESSURE/ } \\
\text { UNDERPRESSURE }\end{array}$ & 48 & $0.51 \%$ & 19 & $39.58 \%$ & 24 & $50.00 \%$ & 5 & $10.42 \%$ \\
\hline EN16 & SOUND LEVEL & 4 & $0.04 \%$ & 3 & $75.00 \%$ & 0 & $0.00 \%$ & 1 & $25.00 \%$ \\
\hline EN17 & $\begin{array}{l}\text { WEATHER, } \\
\text { EARTHQUAKE, } \\
\text { ETC. }\end{array}$ & 134 & $1.43 \%$ & 49 & $36.57 \%$ & 61 & $45.52 \%$ & 24 & $17.91 \%$ \\
\hline EN18 & OTHER & 3,018 & $32.25 \%$ & 1,163 & $38.54 \%$ & 1,586 & $52.55 \%$ & 269 & $8.91 \%$ \\
\hline \multicolumn{2}{|c|}{ TOTAL } & 9,358 & $100.00 \%$ & 3,124 & & 5,210 & & 1,024 & \\
\hline & HUMAN FACTOR & Frequency & Percent & Fatality & Percent & Hospitalized & Percent & $\begin{array}{c}\text { Non- } \\
\text { Hospitalized }\end{array}$ & Percent \\
\hline HU1 & $\begin{array}{l}\text { MISJUDGMENT, } \\
\text { HAZ. SITUATION }\end{array}$ & 2,960 & $31.63 \%$ & 1,051 & $35.51 \%$ & 1,580 & $53.38 \%$ & 329 & $11.11 \%$ \\
\hline HU2 & $\begin{array}{l}\text { NO PERSONAL } \\
\text { PROTECTIVE EQ } \\
\text { USED }\end{array}$ & 12 & $0.13 \%$ & 7 & $58.33 \%$ & 3 & $25.00 \%$ & 2 & $16.67 \%$ \\
\hline HU3 & $\begin{array}{l}\text { NO APPROPR } \\
\text { PROTECTIVE } \\
\text { CLOTHING }\end{array}$ & 1 & $0.01 \%$ & 0 & $0.00 \%$ & 1 & $100.00 \%$ & 0 & $0.00 \%$ \\
\hline HU4 & $\begin{array}{l}\text { MALFUNC IN } \\
\text { SECURING/ } \\
\text { WARNING OP }\end{array}$ & 554 & $5.92 \%$ & 143 & $25.81 \%$ & 333 & $60.11 \%$ & 78 & $14.08 \%$ \\
\hline
\end{tabular}


Continued of Table 2.

\begin{tabular}{|c|c|c|c|c|c|c|c|c|c|}
\hline & IUMAN FACTOR & Frequency & Percent & Fatality & Percent & Hospitalized & Percent & $\begin{array}{c}\text { Non- } \\
\text { Hospitalized }\end{array}$ & Percent \\
\hline HU5 & $\begin{array}{l}\text { DISTRACTING } \\
\text { ACTIONS BY } \\
\text { OTHERS }\end{array}$ & 48 & $0.51 \%$ & 7 & $14.58 \%$ & 33 & $68.75 \%$ & 8 & $16.67 \%$ \\
\hline HU6 & $\begin{array}{l}\text { EQUIP. INAPPROPR } \\
\text { FOR OPERATION }\end{array}$ & 517 & $5.52 \%$ & 169 & $32.69 \%$ & 291 & $56.29 \%$ & 57 & $11.03 \%$ \\
\hline HU7 & $\begin{array}{l}\text { MALFUNC, } \\
\text { NEUROMUSCULAR } \\
\text { SYSTEM }\end{array}$ & 46 & $0.49 \%$ & 8 & $17.39 \%$ & 37 & $80.43 \%$ & 1 & $2.17 \%$ \\
\hline HU8 & $\begin{array}{l}\text { PERCEPTION } \\
\text { MALFUNC,TASK- } \\
\text { ENVIR. }\end{array}$ & 158 & $1.69 \%$ & 37 & $23.42 \%$ & 101 & $63.92 \%$ & 20 & $12.66 \%$ \\
\hline HU9 & $\begin{array}{l}\text { SAFETY DEVICES } \\
\text { REMOVED/INOPER. }\end{array}$ & 784 & $8.38 \%$ & 232 & $29.59 \%$ & 487 & $62.12 \%$ & 65 & $8.29 \%$ \\
\hline HU10 & $\begin{array}{l}\text { POSITION } \\
\text { INAPROPRIATE } \\
\text { FOR TASK } \\
\end{array}$ & 593 & $6.34 \%$ & 177 & $29.85 \%$ & 359 & $60.54 \%$ & 57 & $9.61 \%$ \\
\hline HU11 & $\begin{array}{l}\text { MATER-HANDLG } \\
\text { PROCED. } \\
\text { INAPPROPR }\end{array}$ & 456 & $4.87 \%$ & 139 & $30.48 \%$ & 264 & $57.89 \%$ & 53 & $11.62 \%$ \\
\hline HU12 & $\begin{array}{l}\text { DEFECTIVE } \\
\text { EQUIPMENT IN USE }\end{array}$ & 73 & $0.78 \%$ & 23 & $31.51 \%$ & 41 & $56.16 \%$ & 9 & $12.33 \%$ \\
\hline HU13 & $\begin{array}{l}\text { LOCKOUT/TAGOUT } \\
\text { PROCED MALFUNC }\end{array}$ & 214 & $2.29 \%$ & 77 & $35.98 \%$ & 100 & $46.73 \%$ & 37 & $17.29 \%$ \\
\hline HU14 & $\begin{array}{l}\text { INSUFF/LACK/ } \\
\text { HOUSEKEEPING } \\
\text { PROGRAM }\end{array}$ & 30 & $0.32 \%$ & 5 & $16.67 \%$ & 21 & $70.00 \%$ & 4 & $13.33 \%$ \\
\hline HU15 & $\begin{array}{l}\text { INSUFF/LACK/ } \\
\text { EXPOS/BIOLOGCL } \\
\text { MNTRG. }\end{array}$ & 3 & $0.03 \%$ & 2 & $66.67 \%$ & 1 & $33.33 \%$ & 0 & $0.00 \%$ \\
\hline HU16 & $\begin{array}{l}\text { INSUFF/LACK/ } \\
\text { ENGINEERNG } \\
\text { CONTROLS }\end{array}$ & 255 & $2.72 \%$ & 105 & $41.18 \%$ & 114 & $44.71 \%$ & 36 & $14.12 \%$ \\
\hline HU17 & $\begin{array}{l}\text { INSUFF/LACK/ } \\
\text { WRITN WRK PRAC } \\
\text { PROG. }\end{array}$ & 174 & $1.86 \%$ & 81 & $46.55 \%$ & 74 & $42.53 \%$ & 19 & $10.92 \%$ \\
\hline HU18 & $\begin{array}{l}\text { INSUFF/LACK/ } \\
\text { RESPIRATORY } \\
\text { PROCTECT } \\
\end{array}$ & 19 & $0.20 \%$ & 9 & $47.37 \%$ & 10 & $52.63 \%$ & 0 & $0.00 \%$ \\
\hline HU19 & $\begin{array}{l}\text { INSUF/LACK/ } \\
\text { PROTCV WRK } \\
\text { CLTHG/EQUIP }\end{array}$ & 370 & $3.95 \%$ & 166 & $44.86 \%$ & 182 & $49.19 \%$ & 22 & $5.95 \%$ \\
\hline HU20 & OTHER & 2,091 & $22.34 \%$ & 686 & $32.81 \%$ & 1,178 & $56.34 \%$ & 227 & $10.86 \%$ \\
\hline \multicolumn{2}{|c|}{ TOTAL } & 9,358 & $100.00 \%$ & 3,124 & & 5,210 & & 1,024 & \\
\hline
\end{tabular}

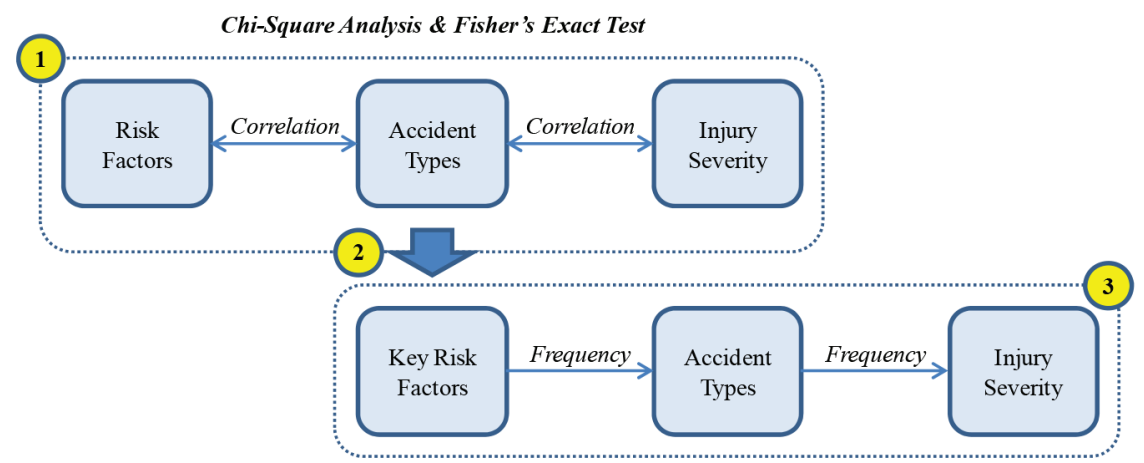

Fig. 1. Conceptual analysis structure 
Table 3. Example statistics for Fisher's exact test

\begin{tabular}{ccc}
\hline Misjudgment & Fatality & Non-fatality \\
\hline Yes & 5 & 0 \\
\hline No & 1 & 4 \\
\hline
\end{tabular}

$R_{i}$ and $C_{j}$ represent the row and column sums, and $N$ is the total sum of $R_{i}$ or the total sum of $C_{j}$. In Table $3, R_{1}=5$ $R_{1}=5$ and $R_{2}=5 . C_{1}=6$ and $C_{2}=4 . N$ is 10 that equals the sum of $R_{i}$ and the sum of $C_{j}$. Fisher's exact test then calculates the condition probability of the matrix with this information and defines it as $P_{\text {cutoff }}$ (Eqn (1)):

$$
P_{\text {cutoff }}=\frac{\left(R_{1} ! R_{2} ! \ldots R_{m} !\right)\left(C_{1} ! C_{2} ! \ldots C_{n} !\right)}{N ! \Pi_{i j} a_{i j} !} .
$$

In this example, $P_{\text {cutoff }}$ is 0.0238 . The test then calculates the conditional probability of every possible matrix with the fixed and values based on the same equation. For instance, is one possible matrix and the conditional probability of this matrix is 0.0238 . For the matrix of the conditional probability is 0.2381 . This individual p-value is compared with $P_{\text {cutoff }}$ and the sum of p-values less than or equal to $P_{\text {cutoff }}$ becomes the representative $\mathrm{p}$ value of the test. In this example, the representative $\mathrm{p}$-value is calculated as 0.0476 . If this $p$-value is less than $0.05(5 \%)$ or $0.01(1 \%)$ depending on the analysis purpose, the null hypothesis should be rejected, which means that there is a significant correlation between the two variables. If 5\% is set as an acceptable significance level, the representative value of our example becomes less than 0.05 and thus there is a significant association between the misjudgement of a hazardous situation and a fatality. As shown in Table 3, worker misjudgement caused most of the fatalities.

The research then determined the significant risk factors highly correlated to injury severity for each accident type through the Chi-square analysis and Fisher's exact test in order to prioritize the risk factors for effective control of injury occurrence (\#2 in Fig. 1). Once identifying the key risk factors, the research analysed the likelihood of an accident and a fatality that may be caused by the identified key factors (\#3 in Fig. 1). The frequency of the key risk factors contributed to different injury severity was measured for each accident type and each accident causation path was empirically and statistically analysed.

\section{Results and discussion}

\subsection{Relationships among risk factors, accident types, and injury severity}

Table 4 summarizes the frequency of different risk factors for each accident type, including falls from an elevation, struck-by, caught in/or between, electrical shock, struckagainst, inhalation, respiratory failure and falls at the same level. Each observation frequency was counted by the authors by using Microsoft Excel functions. Based on the observed frequency, the authors identified the key risk factors of each accident type if their frequency account- ed for more than $10 \%$ of the total accidents. As shown in the table, misjudgement of hazardous situations was the most common contributing factor for every type of accident, comprising more than $30 \%$ of all cases in general. In other words, by reducing worker misjudgement probably through supervision or training supports more than $30 \%$ of the accidents, such as the one described below, could have been avoided: "A supervisor was talking on his cell phone, unaware of the forklift that was backing up beside him. He was struck by the forklift and sustained fractures to his foot and ankle. He was hospitalized for his injuries." (OSHA 2007).

Accidents involving falls from an elevation were associated with working surface and facility layout conditions, and safety devices having been removed or being inoperative, such as in the following example: "An employee was installing a roof ending intended to prevent the formation of ice dams. Although a harness, a lanyard, and a rope were available on the roof, he was not wearing the harness and lanyard. No slide guards had been installed along the lower leading edge of the roof adjacent to the eaves, either. The employee lost his footing and slipped off the roof from a height of 34 feet. He landed head first on the ground, and he was killed, due to a head concussion." (OSHA 2006). This observation indicated that falling accidents can be a result of the working surface being slippery, or when falling protection devices such as guiderails or safety nets are missing, defective or inappropriately used. By controlling these risk factors, about $61 \%$ of the falling accidents were preventable.

About $53 \%$ of struck-by accidents were associated with flying object action, overhead moving and/or falling object action, and materials handling equipment/method, as illustrated below: "An employee was working at a commercial building under construction. He was trying to secure two frames, one on each side of an opening for a door, to each other. When he removed the clamp holding the frame to the wall on one side, the 300-lb door frame assembly fell on him. He sustained a minor concussion." (OSHA 2005). Such struck-by accidents can occur during construction operation or materials handling if there are inappropriate operating procedures or materials handling practices.

Caught in/or between accidents were closely related to required construction machinery operations; pinch point and squeeze point actions were the major causes of these accidents, for example: "A concrete sub-contractor was working on the concrete foundation at the site of the accident. He was drilling holes in a wood form when his glove got caught in the bit, pulling his right index finger off at the first joint." (OSHA 2011). By eliminating inappropriate operations or inattentiveness about $43 \%$ of the caught in/or between accidents could have been prevented.

Of the electrical shock accidents, $31 \%$ resulted from inappropriate materials handling and work surface or facility layout conditions as illustrated in the following example: "A crane operator was using a truck-mounted lattice boom crane at a construction site. The $110 \mathrm{ft}$ long 


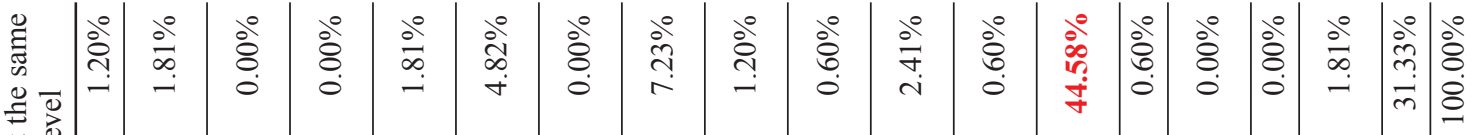

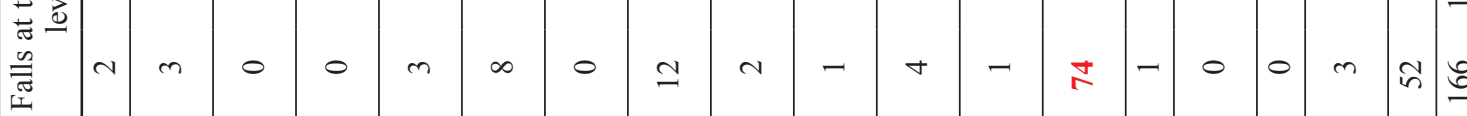

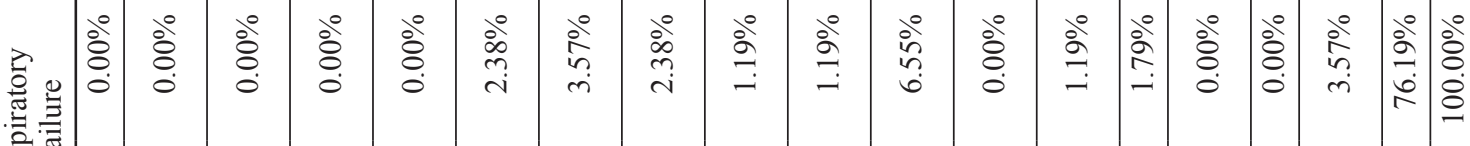

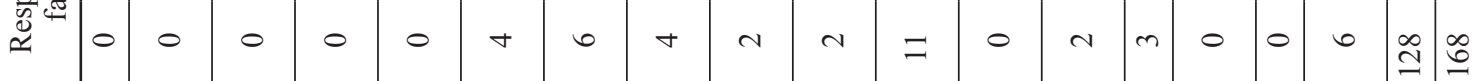

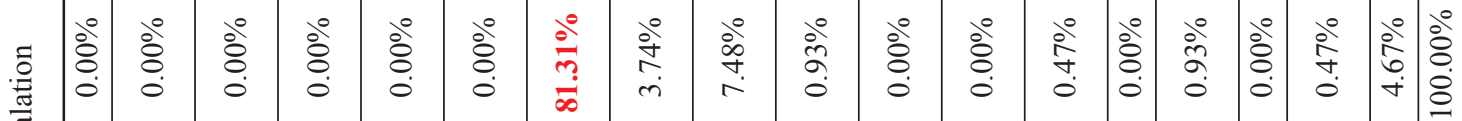
J

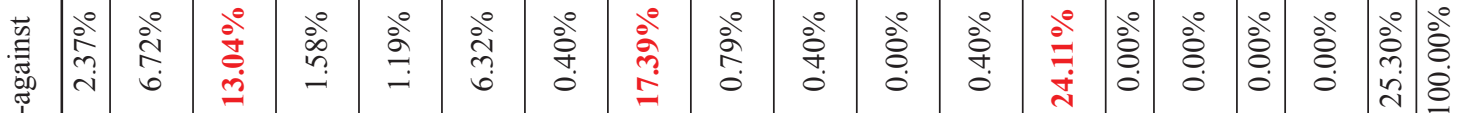
竞

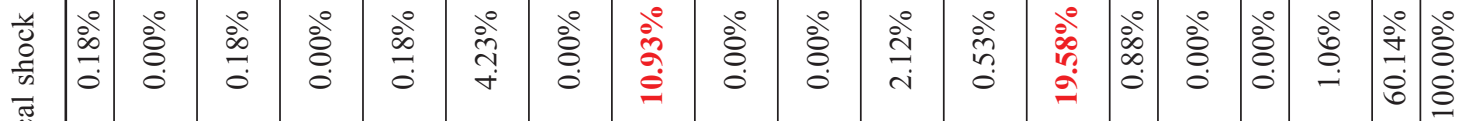
$\frac{5}{4}$

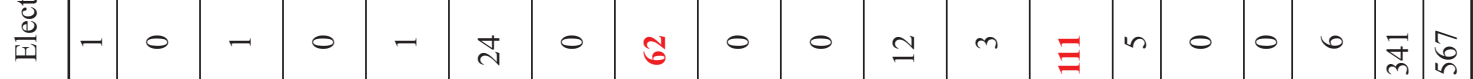

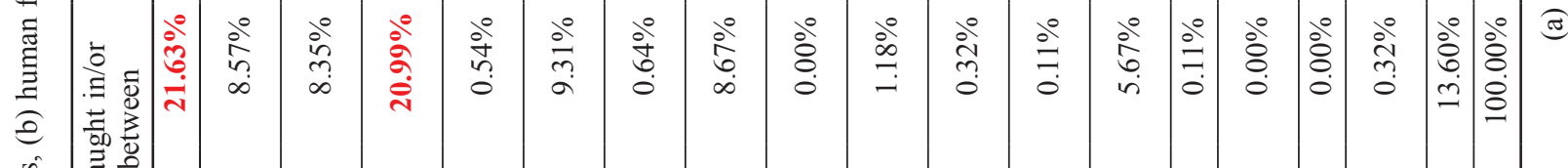

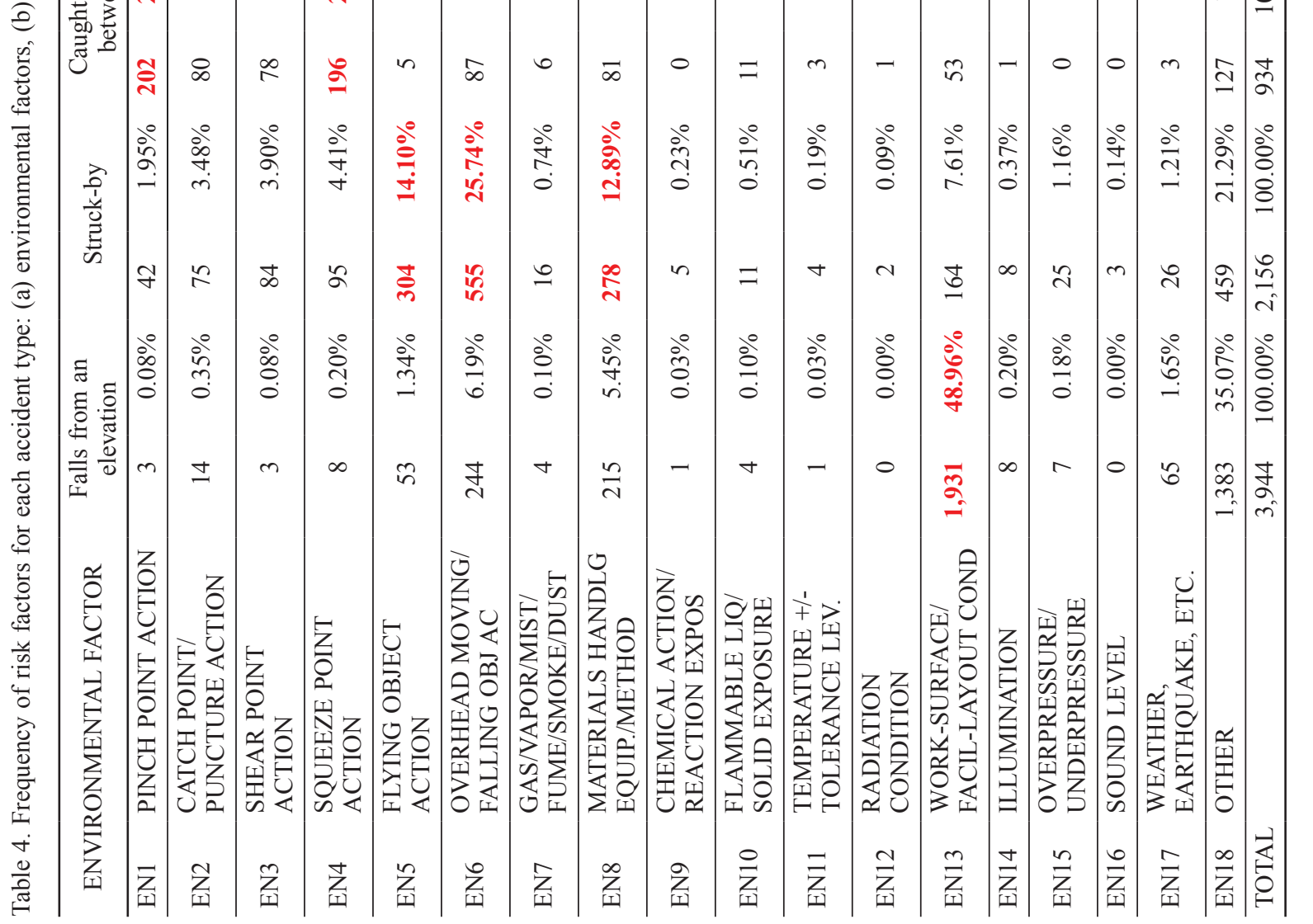


$\sqrt{1}$

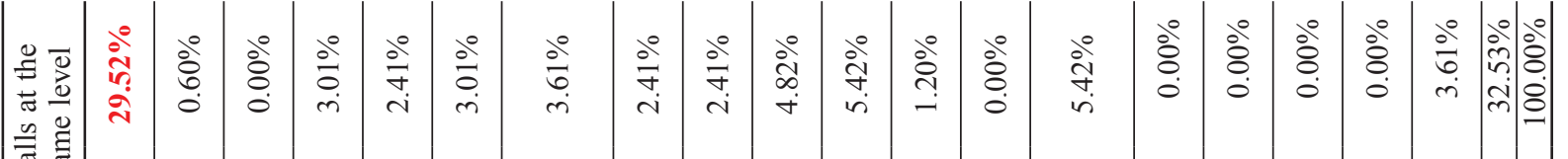 压

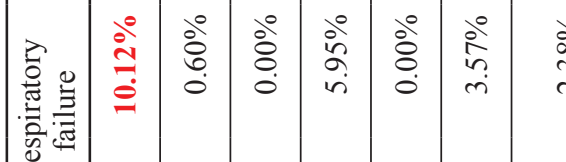
$\approx$
今े

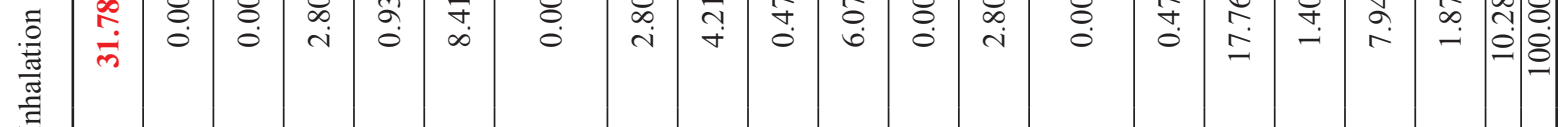

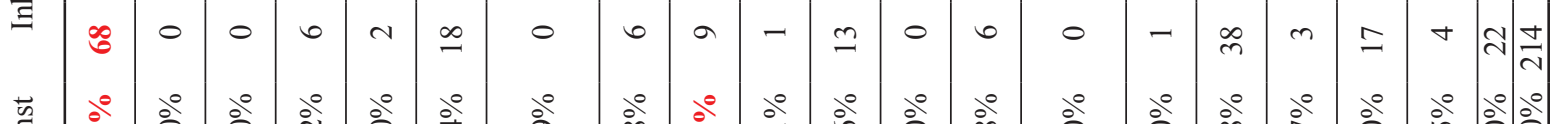

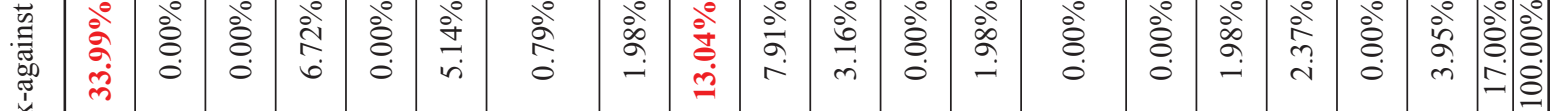

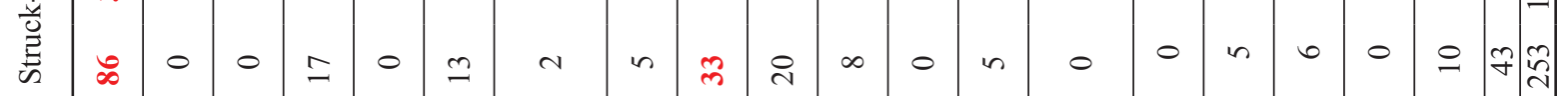

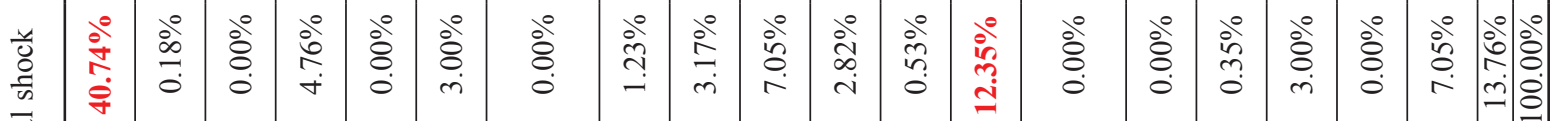

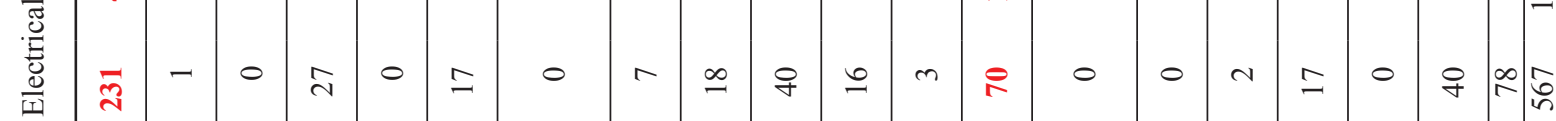

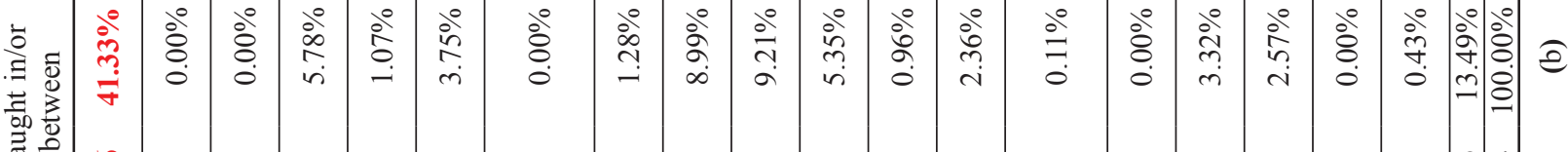
U

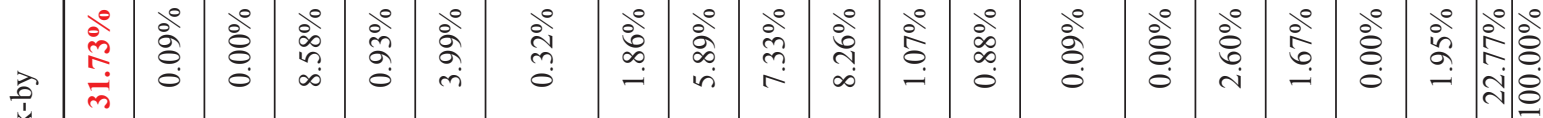
总

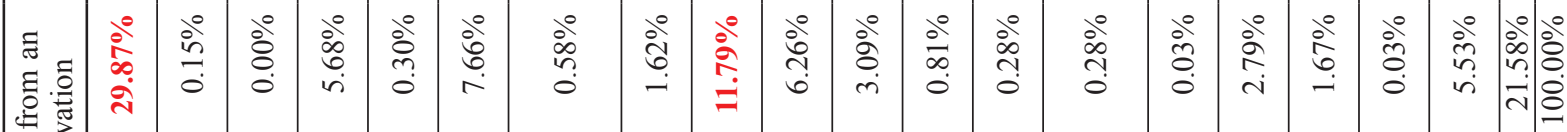

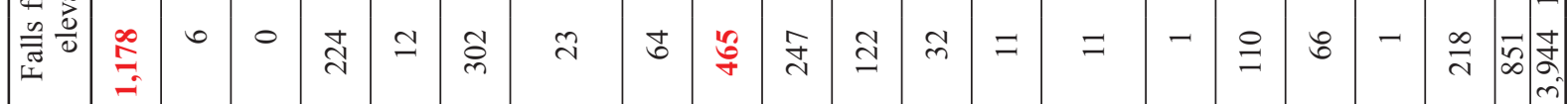

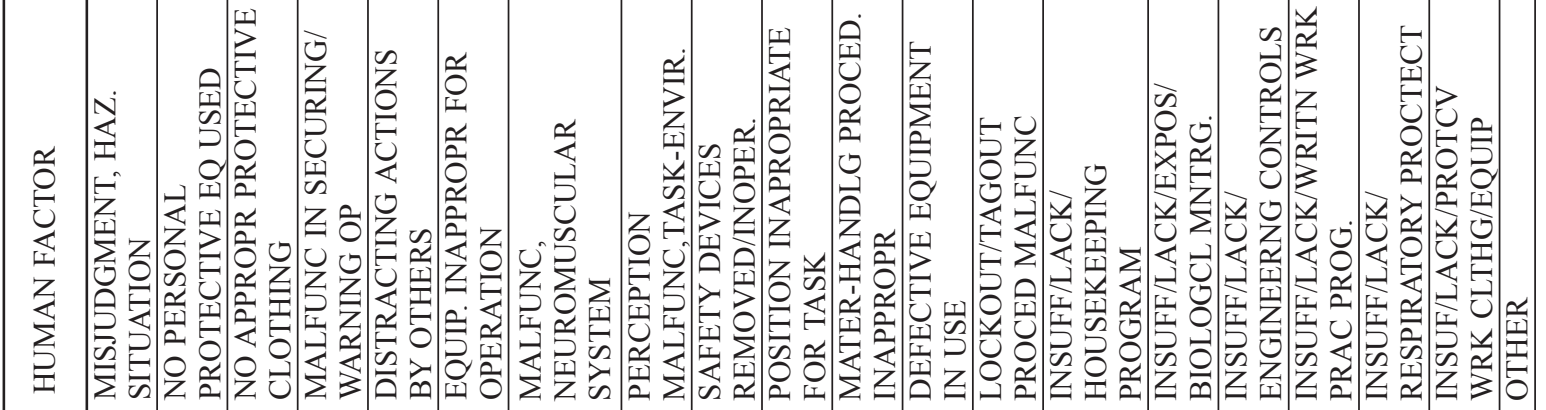

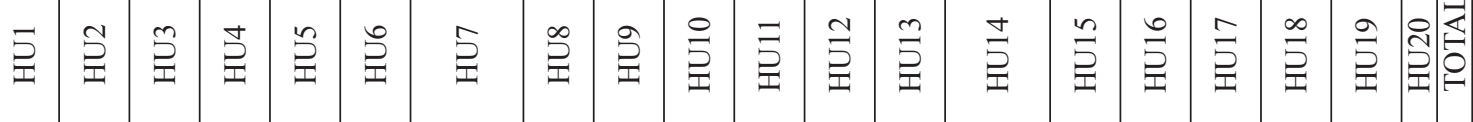


boom was in the 'up' position and the clutch was engaged when he exited the cab to speak to the foreman of the steel erection crew. The boom suddenly began to descend toward the ground and he tried to re-enter the cab to stop it. He reached the outrigger just as the main hoist line contacted overhead power lines and he was electrocuted." (OSHA 2002a). The contact of heavy equipment with electrical powerlines during materials handling is one of the critical risks causing electrocution; if steel works are performed near powerlines or generators, there is a high likelihood of a worker being electrocuted. Additionally, malfunction of procedures for lock-out or tag-out was also identified as being one of the major human factors contributing to $12 \%$ of shock accidents. For example: "An experienced but unlicensed electrician was performing a routine task in a motor control vault on a construction site. The electrician applied a lock-out/tag-out procedure to the first cabinet and then opened a second vault cabinet. He came in contact with energized components and was electrocuted since the components in the second vault cabinet were not protected by a lock-out procedure as was performed on the first cabinet." (OSHA 2008). Proper layout planning, materials handling and communication practices will help reduce such accidents.

Next, shear point action, improper materials handling operation, and work surface and facility layout conditions accounted for $54 \%$ of struck-against accidents. For example: "An employee was trimming wood particle board. He was using a table saw. At the time of the inspection, this table saw had the appropriately installed hood guard and splitter. He had this hood guard flipped open for convenience when he lost balance and his left hand came in contact with the rotating blade. His left fingers were amputated at the first knuckle." (OSHA 2004). A poor working surface or shear point action may lead to workers slipping, resulting in being struck-against surrounding objects or structures. The facility layout can similarly control workers' stability. About $13 \%$ of such struck-against accidents could be reduced by the proper use of safety devices as explained in the following example: "An employee was utilizing a circular table saw from which he had removed the blade guard. His hand slipped in the process of cutting one of the wood sheets and his left thumb was struck against the unguarded blade, resulting in a severe laceration to the left thumb." (OSHA 2003a).

Eighty-one percent of inhalation accidents were highly associated with gas, vapor, mist, fume, smoke or dust conditions, such as in the following incident: "An employee was finishing a concrete floor in an enclosed basement. After he noticed headaches and nausea, he went to a nearby convenience store to get aspirin, and he collapsed. He was transported for treatment in a hyperbaric chamber. The emergency responder measured 740 ppm of carbon monoxide in the basement area." (OSHA 2002b). It is important to open windows or doors in confined spaces to maintain proper ventilation, to control indoor air quality continuously and to use appropriate respiratory protection.

There was no high frequency ( $10 \%$ or more) risk factor for cardiothoracic and vascular or respiratory failure, some of which occurred due to the temperature being above or below tolerance level, or the malfunction of procedures for securing an operation or warning of a hazardous situation. Contacts with energized objects can cause serious skin burning or heart attack leading to respiratory problems. Working in a high temperature above the tolerance level may cause workers to collapse from sunstroke. Having proper procedures in place for securing an operation, warning of a hazardous situation or taking frequent breaks when working in a high temperature would help to avoid such accidents, an example of which is described below: "An employee was attempting to tie in reinforced steel to a floor slab of a culvert in a wooded area. The weather conditions were 99 degrees Fahrenheit heat index. The site superintendent noticed that the employee was having trouble working and appeared sick and told him to take a break and to go sit in the shade, but he insisted that he was okay and continued to work. Soon after this incident, he stood briefly while working and collapsed. He was pronounced dead due to ischemic heart disease and hypertension." (OSHA 2003b).

Lastly, falls at the same level were closely related to working surface and facility layout conditions, for example: "An experienced carpenter for a residential framing company finished his shift at a construction site and was walking to his car. He tripped over a plastic sewer pipe, fell, and fractured his left hip." (OSHA 2002c). About 45\% of such accidents could be controlled by maintaining proper surface and layout conditions in the working environment and by implementing good housekeeping practices.

The correlation between the risk factors (either environmental or human risk factors) and the accident type was significant with the less than $1 \% p$-value verifying different risk factors result in different accident types. The relationship between the accident type and the injury severity was also investigated. As shown in Table 1 earlier, the observation showed that the fatality rate for electrical shock accidents $(65 \%)$ and respiratory failure $(96 \%)$ was higher than the rate for other accident types due to high voltage and toxic gases leading to death. About $30 \%$ of fatality rates were identified as resulting from most of the other accident types and their likelihood of having hospitalized injuries was much higher than the likelihood of having non-hospitalized injuries. The low frequency of non-hospitalized injuries indicated that most construction accidents are severe and require lost working days due to the injury. This is critical considering both direct and indirect costs of injury compensation. Falls from an elevation (42\%), struck-by (23\%), and caught in/or between $(10 \%)$ accidents were the top three accident types that accounted for $75 \%$ of the total workplace injuries in the construction industry. That could be why a larger 
number of key risk factors were previously identified for these accident categories than for other accident types. The correlation between the accident type and the injury severity was significant with the less than $1 \% p$-value.

\subsection{Key risk factors of each accident type that are correlated to injury severity}

The authors also determined significant risk factors of each accident type that are highly correlated to injury severity which could be controlled in order to manage the likelihood of fatal injuries on construction sites. In this study, a $p$-value of $0.01(1 \%)$ or less was chosen as an acceptable significance level for more reliable analysis considering the large number of sample sizes obtained from the accident data. Table 5 summarizes the analysis results. Each cell represents the $p$-value, the significance between two compared variables: one from the risk factor; and the other from the injury severity, either fatality, hospitalized or non-hospitalized. No statistics were computed when the variable was a constant; for instance, all accidents involving falls from an elevation were not related to radiation condition (EN12). The analysis distinguished the significant risk factors which contributed to determining injury severity.

For falls from an elevation, the high impact factors determining injury severity were: flying object action (EN5), overhead moving and/or falling object action (EN6), working surface/facility layout condition (EN13), weather/earthquake, etc. (EN17), malfunction of procedures for securing operations or warning of a hazardous situation (HU4), safety devices removed or inoperative (HU9), and insufficient or lack of protective work clothing and equipment (HU19). For instance, the proper installation or appropriate use of safety devices and a sufficient supply of PPE can reduce the likelihood of fatal fall injuries. Severe falling accidents could also be avoided by controlling overhead moving or falling objects or by providing a proper warning procedure for hazardous situations.

There were six risk factors associated with the injury severity of struck-by accidents: catch point action (EN2), shear point action (EN3), flying object action (EN5), materials handling equipment/method (EN8), illumination (EN14), and misjudgement of hazardous situations (HU1). The $p$-value determined that proper materials handling processes can prevent fatal struck-by accidents. Illumination conditions were correlated to such accidents as they would determine the worker's sight of view. By providing sufficient supervision or safety training to prevent workers' misjudgement, the fatal struck-by accidents could be avoided.

Caught in/or between accidents were highly correlated to machinery-related environmental factors (EN1, EN2, EN3). Proper operational procedure, engineering controls (HU16) or supervision, and appropriate materials handling (EN8) may reduce the number of severe caught in/between accidents since these actions will enhance working environment safety. The accident's severity was also determined by overhead moving, and/or falling object action (EN6), working surface/facility layout conditions (EN13), and distracting actions by others (HU5).

Electrical shocks were heavily related to the temperature being above or below tolerance level (EN11). Contact with energized objects or overhead powerlines increases the temperature well above the tolerance level, causing serious skin burns or heart attacks. The number of fatal struck-against accidents could be minimized by controlling shear point action (EN3), preventing safety devices being removed or inoperative (HU9), or the positioning of sufficient protection work clothing and equipment (HU19). There was no significant factor determining the severity of inhalation; however, safety devices being removed or inoperative (HU9), malfunction of lock-out or tag-out procedures (HU13), insufficient or lack of a written work practices program (HU17), and insufficient or lack of respiratory protection (HU18) could be important if a $0.05(5 \%)$ or less acceptance level was applied as a threshold. Gas, vapor, mist, fume, smoke, or dust conditions (EN7) and the malfunction of procedures for securing an operation or warning of hazardous situations (HU4) were identified as being significant factors that can prevent fatal respiratory failure. Lastly, two environment-related factors including pinch point action (EN1) and overhead moving and/or falling object action (EN6) were determined as major risk factors in fatal accidents involving falls at the same level.

\subsection{Impact of the identified key factors on accident and fatality occurrence}

The authors then analysed the likelihood of an accident and a fatality that may be caused by the identified key factors. The frequency of the key risk factors contributed to different injury severity was measured for each accident type and each accident causation path was empirically and statistically analysed. Table 6 summarizes the analysis results. 29 key relationships between risk factors and accident types (e.g. illumination and struck-by accident, safety devices removed/or inoperative and falls from an elevation) were first extracted from the previous analysis discussed in Table 5. For each pair, accident frequency and the likelihood of the accident caused by the identified risk factor were measured. For instance, the flying object action caused 304 struck-by accidents and they accounted for $14.1 \%$ of the total struck-by accidents $(2,156)$. In other words, $14.1 \%$ of the struck-by accidents can be managed by controlling risk factors associated with the flying object action. Figure 2 illustrates the identified key relationships. The larger likelihood than $10 \%$ was indicated as a straight line and a dash line represented the smaller likelihood than $10 \%$. The authors also counted the frequency of fatality caused by the pair. Among the 304 struck-by accidents, 58 accidents were fatalities. Thus, $7.8 \%$ of the total fatal struck-by accidents (746) might be reduced by addressing the risky flying object action. 
Table 5. Significant risk factors and their correlation to injury severity

\begin{tabular}{|c|c|c|c|c|c|c|c|c|c|}
\hline \multirow[b]{2}{*}{ ID } & \multirow[b]{2}{*}{ Risk factors } & \multicolumn{8}{|c|}{ Correlation to Injury Severity for Different Accident Types } \\
\hline & & $\begin{array}{l}\text { Falls } \\
\text { from an } \\
\text { elevation }\end{array}$ & $\begin{array}{l}\text { Struck- } \\
\text { by }\end{array}$ & $\begin{array}{l}\text { Caught } \\
\text { in/or } \\
\text { between }\end{array}$ & $\begin{array}{l}\text { Electrical } \\
\text { shock }\end{array}$ & $\begin{array}{l}\text { Struck- } \\
\text { against }\end{array}$ & Inhalation & $\begin{array}{l}\text { Respiratory } \\
\text { failure }\end{array}$ & $\begin{array}{l}\text { Falls } \\
\text { at the } \\
\text { same } \\
\text { level }\end{array}$ \\
\hline EN1 & PINCH POINT ACTION & 1.000 & .018 & .000 & .067 & .621 & * & * & .009 \\
\hline EN2 & $\begin{array}{l}\text { CATCH POINT/PUNCTURE } \\
\text { ACTION }\end{array}$ & .471 & .000 & .000 & $*$ & .102 & $*$ & $*$ & .596 \\
\hline EN3 & SHEAR POINT ACTION & .247 & .000 & .000 & .351 & .000 & * & $*$ & $*$ \\
\hline EN4 & SQUEEZE POINT ACTION & 1.000 & .122 & .022 & $*$ & 1.000 & $*$ & $*$ & $*$ \\
\hline EN5 & FLYING OBJECT ACTION & .000 & .000 & 1.000 & .351 & .745 & $*$ & $*$ & 1.000 \\
\hline EN6 & $\begin{array}{l}\text { OVERHEAD MOVING/ } \\
\text { FALLING OBJ AC } \\
\end{array}$ & .001 & .100 & .005 & .608 & .096 & $*$ & .863 & .004 \\
\hline EN7 & $\begin{array}{l}\text { GAS/VAPOR/MIST/FUME/ } \\
\text { SMOKE/DUST }\end{array}$ & .156 & .357 & .326 & $*$ & .170 & .854 & .000 & $*$ \\
\hline EN8 & $\begin{array}{l}\text { MATERIALS HANDLG } \\
\text { EQUIP./METHOD }\end{array}$ & .573 & .004 & .001 & .629 & .431 & .522 & .863 & .465 \\
\hline EN9 & $\begin{array}{l}\text { CHEMICAL ACTION/ } \\
\text { REACTION EXPOS }\end{array}$ & 1.000 & .828 & $*$ & $*$ & .100 & .181 & .930 & .452 \\
\hline EN10 & $\begin{array}{l}\text { FLAMMABLE LIQ/SOLID } \\
\text { EXPOSURE }\end{array}$ & .352 & .577 & .095 & $*$ & .439 & 1.000 & .930 & 1.000 \\
\hline EN11 & $\begin{array}{l}\text { TEMPERATURE +/- } \\
\text { TOLERANCE LEV. }\end{array}$ & 1.000 & .270 & .403 & .010 & $*$ & $*$ & .662 & .170 \\
\hline EN12 & RADIATION CONDITION & $*$ & .363 & 1.000 & 1.000 & 1.000 & $*$ & $*$ & .259 \\
\hline EN13 & $\begin{array}{l}\text { WORK-SURFACE/FACIL- } \\
\text { LAYOUT COND }\end{array}$ & .008 & .148 & .000 & .278 & .640 & .542 & .930 & .064 \\
\hline EN14 & ILLUMINATION & .852 & .010 & 1.000 & .527 & $*$ & $*$ & .896 & 1.000 \\
\hline EN15 & $\begin{array}{l}\text { OVERPRESSURE/ } \\
\text { UNDERPRESSURE }\end{array}$ & 1.000 & .337 & $*$ & $*$ & $*$ & .712 & $*$ & $*$ \\
\hline EN16 & SOUND LEVEL & $*$ & .087 & $*$ & $*$ & $*$ & $*$ & $*$ & $*$ \\
\hline EN17 & $\begin{array}{l}\text { WEATHER, EARTHQUAKE, } \\
\text { ETC. }\end{array}$ & .000 & .156 & .170 & .588 & $*$ & .542 & .199 & .596 \\
\hline HU1 & $\begin{array}{l}\text { MISJUDGMENT, HAZ. } \\
\text { SITUATION }\end{array}$ & .653 & .003 & .318 & .821 & .216 & .104 & .478 & .920 \\
\hline HU2 & $\begin{array}{l}\text { NO PERSONAL } \\
\text { PROTECTIVE EQ USED }\end{array}$ & .069 & 1.000 & $*$ & 1.000 & $*$ & $*$ & .964 & .259 \\
\hline HU3 & $\begin{array}{l}\text { NO APPROPR PROTECTIVE } \\
\text { CLOTHING }\end{array}$ & $*$ & * & $*$ & $*$ & $*$ & $*$ & $*$ & $*$ \\
\hline HU4 & $\begin{array}{l}\text { MALFUNC IN SECURING/ } \\
\text { WARNING OP }\end{array}$ & .000 & .012 & .675 & .021 & .039 & .576 & .003 & .067 \\
\hline HU5 & $\begin{array}{l}\text { DISTRACTING ACTIONS BY } \\
\text { OTHERS }\end{array}$ & .271 & .859 & .004 & $*$ & * & .501 & $*$ & 1.000 \\
\hline HU6 & $\begin{array}{l}\text { EQUIP. INAPPROPR FOR } \\
\text { OPERATION }\end{array}$ & .141 & .731 & .202 & .842 & .736 & .266 & .801 & .533 \\
\hline HU7 & $\begin{array}{l}\text { MALFUNC, } \\
\text { NEUROMUSCULAR } \\
\text { SYSTEM }\end{array}$ & .177 & .041 & $*$ & $*$ & 1.000 & $*$ & .863 & .780 \\
\hline HU8 & $\begin{array}{l}\text { PERCEPTION } \\
\text { MALFUNC,TASK-ENVIR. }\end{array}$ & .038 & .833 & .067 & .656 & .372 & .486 & .896 & 1.000 \\
\hline HU9 & $\begin{array}{l}\text { SAFETY DEVICES } \\
\text { REMOVED/INOPER. }\end{array}$ & .007 & .467 & .019 & .921 & .001 & .020 & .964 & .170 \\
\hline HU10 & $\begin{array}{l}\text { POSITION INAPROPRIATE } \\
\text { FOR TASK }\end{array}$ & .084 & .419 & .719 & .393 & .949 & 1.000 & .964 & .841 \\
\hline HU11 & & .222 & .154 & .558 & .178 & .4214 & .277 & .930 & .138 \\
\hline
\end{tabular}


Continued of Table 5.

\begin{tabular}{|c|c|c|c|c|c|c|c|c|c|}
\hline \multirow[b]{2}{*}{ ID } & \multirow[b]{2}{*}{ Risk factors } & \multicolumn{8}{|c|}{ Correlation to Injury Severity for Different Accident Types } \\
\hline & & $\begin{array}{l}\text { Falls } \\
\text { from an } \\
\text { elevation }\end{array}$ & $\begin{array}{l}\text { Struck- } \\
\text { by }\end{array}$ & $\begin{array}{l}\text { Caught } \\
\text { in/or } \\
\text { between }\end{array}$ & $\begin{array}{l}\text { Electrical } \\
\text { shock }\end{array}$ & $\begin{array}{l}\text { Struck- } \\
\text { against }\end{array}$ & Inhalation & $\begin{array}{l}\text { Respiratory } \\
\text { failure }\end{array}$ & $\begin{array}{l}\text { Falls } \\
\text { at the } \\
\text { same } \\
\text { level }\end{array}$ \\
\hline HU12 & $\begin{array}{l}\text { DEFECTIVE EQUIPMENT } \\
\text { IN USE }\end{array}$ & .561 & .532 & .350 & .640 & * & $*$ & .964 & 1.000 \\
\hline HU13 & $\begin{array}{l}\text { LOCKOUT/TAGOUT } \\
\text { PROCED MALFUNC }\end{array}$ & .053 & .202 & .564 & .175 & .835 & .050 & .772 & $*$ \\
\hline HU14 & $\begin{array}{l}\text { INSUFF/LACK/ } \\
\text { HOUSEKEEPING PROGRAM }\end{array}$ & .174 & .637 & 1.000 & $*$ & $*$ & $*$ & * & .606 \\
\hline HU15 & $\begin{array}{l}\text { INSUFF/LACK/EXPOS/ } \\
\text { BIOLOGCL MNTRG. }\end{array}$ & .364 & $*$ & * & * & $*$ & 1.000 & * & $*$ \\
\hline HU16 & $\begin{array}{l}\text { INSUFF/LACK/ } \\
\text { ENGINEERNG CONTROLS }\end{array}$ & .015 & .740 & .000 & 1.000 & .835 & .191 & .964 & $*$ \\
\hline HU17 & $\begin{array}{l}\text { INSUFF/LACK/WRITN WRK } \\
\text { PRAC PROG. }\end{array}$ & .023 & .020 & .642 & .070 & .728 & .041 & .199 & $*$ \\
\hline HU18 & $\begin{array}{l}\text { INSUFF/LACK/ } \\
\text { RESPIRATORY PROCTECT }\end{array}$ & 1.000 & $*$ & $*$ & $*$ & $*$ & .024 & $*$ & $*$ \\
\hline HU19 & $\begin{array}{l}\text { INSUF/LACK/PROTCV WRK } \\
\text { CLTHG/EQUIP }\end{array}$ & .000 & .084 & .824 & .102 & .002 & .568 & .964 & .342 \\
\hline
\end{tabular}

*No statistics are computed because the variable is a constant.

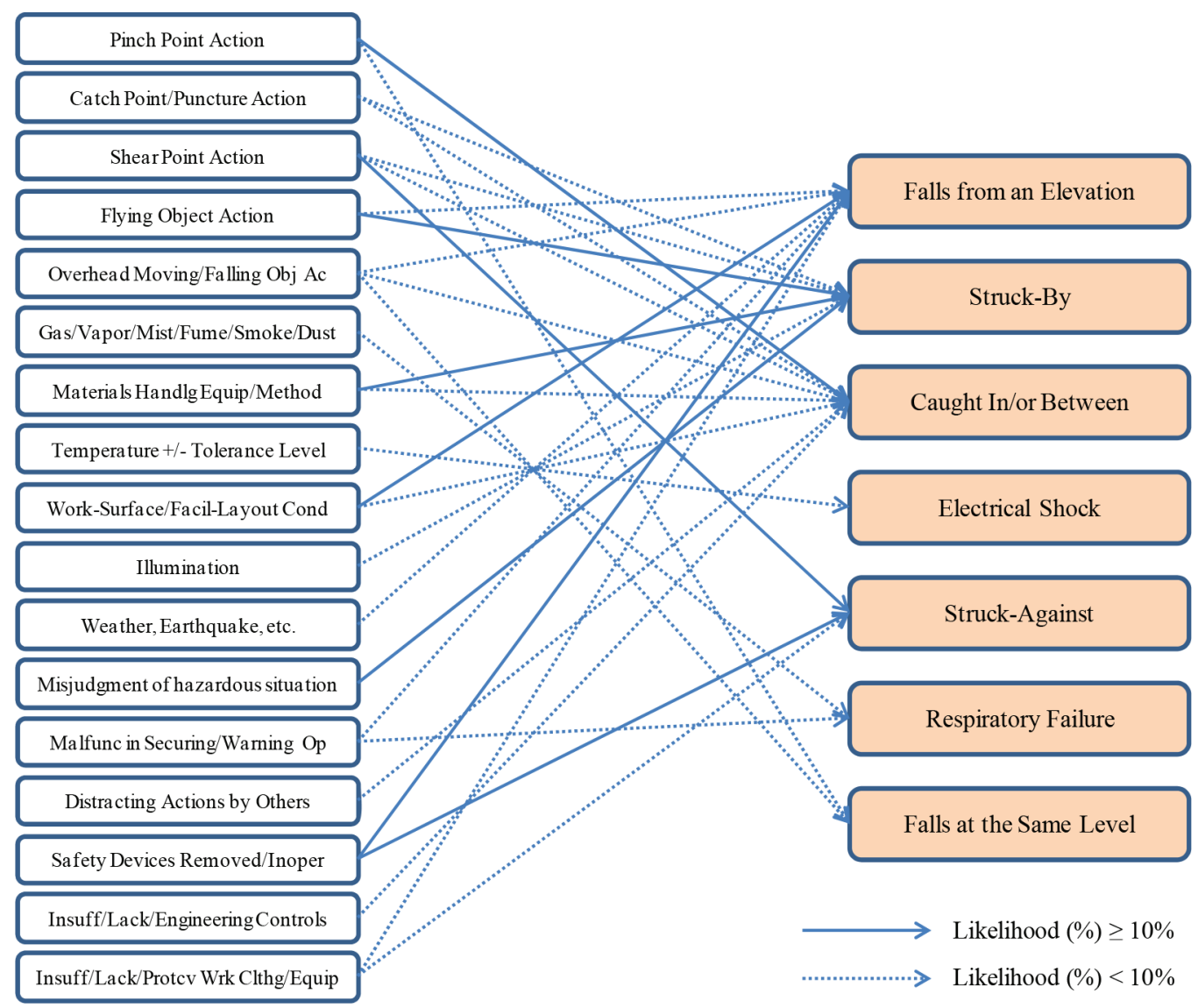

Fig. 2. Key relationships between risk factors and accident types 
Table 6. Impact of key risk factors on accident and fatality occurrence

\begin{tabular}{|c|c|c|c|c|c|c|c|}
\hline Risk factors & $\begin{array}{l}\text { Frequency } \\
\text { of accident }\end{array}$ & $\begin{array}{l}\text { Likelihood } \\
\text { (\%) of } \\
\text { accident }\end{array}$ & Rank & Accident type & $\begin{array}{l}\text { Frequency } \\
\text { of fatality }\end{array}$ & $\begin{array}{l}\text { Likelihood } \\
(\%) \text { of } \\
\text { fatality }\end{array}$ & Rank \\
\hline \multirow{2}{*}{ PINCH POINT ACTION } & 202 & $21.6 \%$ & 3 & $\begin{array}{l}\text { Caught In/ or } \\
\text { Between }\end{array}$ & 40 & $12.3 \%$ & 7 \\
\hline & 2 & $1.2 \%$ & 27 & $\begin{array}{l}\text { Falls at the Same } \\
\text { Level }\end{array}$ & 0 & $0.0 \%$ & 27 \\
\hline \multirow{2}{*}{$\begin{array}{l}\text { CATCH POINT/PUNCTURE } \\
\text { ACTION }\end{array}$} & 75 & $3.5 \%$ & 22 & Struck-By & 7 & $0.9 \%$ & 21 \\
\hline & 80 & $8.6 \%$ & 11 & $\begin{array}{l}\text { Caught In/ or } \\
\text { Between }\end{array}$ & 12 & $3.7 \%$ & 16 \\
\hline \multirow{3}{*}{ SHEAR POINT ACTION } & 84 & $3.9 \%$ & 20 & Struck-By & 4 & $0.5 \%$ & 25 \\
\hline & 78 & $8.4 \%$ & 12 & $\begin{array}{l}\text { Caught In/ or } \\
\text { Between }\end{array}$ & 3 & $0.9 \%$ & 23 \\
\hline & 33 & $13.0 \%$ & 5 & Struck-Against & 0 & $0.0 \%$ & 27 \\
\hline \multirow[t]{2}{*}{ FLYING OBJECT ACTION } & 53 & $1.3 \%$ & 26 & $\begin{array}{l}\text { Falls from an } \\
\text { Elevation }\end{array}$ & 2 & $0.2 \%$ & 26 \\
\hline & 304 & $14.1 \%$ & 4 & Struck-By & 58 & $7.8 \%$ & 11 \\
\hline \multirow{3}{*}{$\begin{array}{l}\text { OVERHEAD MOVING/ } \\
\text { FALLING OBJ AC }\end{array}$} & 244 & $6.2 \%$ & 13 & $\begin{array}{l}\text { Falls from an } \\
\text { Elevation }\end{array}$ & 48 & $4.3 \%$ & 14 \\
\hline & 87 & $9.3 \%$ & 9 & $\begin{array}{l}\text { Caught In/ or } \\
\text { Between }\end{array}$ & 42 & $12.9 \%$ & 5 \\
\hline & 8 & $4.8 \%$ & 18 & $\begin{array}{l}\text { Falls at the Same } \\
\text { Level }\end{array}$ & 1 & $3.7 \%$ & 15 \\
\hline $\begin{array}{l}\text { GAS/VAPOR/MIST/FUME/ } \\
\text { SMOKE/DUST }\end{array}$ & 6 & $3.6 \%$ & 21 & Respiratory Failure & 3 & $1.9 \%$ & 18 \\
\hline \multirow{2}{*}{$\begin{array}{l}\text { MATERIALS HANDLG EQUIP./ } \\
\text { METHOD }\end{array}$} & 278 & $12.9 \%$ & 7 & Struck-By & 120 & $16.1 \%$ & 3 \\
\hline & 81 & $8.7 \%$ & 10 & $\begin{array}{l}\text { Caught In/ or } \\
\text { Between }\end{array}$ & 42 & $12.9 \%$ & 5 \\
\hline $\begin{array}{l}\text { TEMPERATURE +/- } \\
\text { TOLERANCE LEV. }\end{array}$ & 12 & $2.1 \%$ & 24 & Electrical Shock & 3 & $0.8 \%$ & 24 \\
\hline \multirow{2}{*}{$\begin{array}{l}\text { WORK-SURFACE/FACIL- } \\
\text { LAYOUT COND }\end{array}$} & 1,931 & $49.0 \%$ & 1 & $\begin{array}{l}\text { Falls from an } \\
\text { Elevation }\end{array}$ & 574 & $51.5 \%$ & 1 \\
\hline & 53 & $5.7 \%$ & 16 & $\begin{array}{l}\text { Caught In/ or } \\
\text { Between }\end{array}$ & 32 & $9.8 \%$ & 9 \\
\hline ILLUMINATION & 8 & $0.4 \%$ & 29 & Struck-By & 7 & $0.9 \%$ & 21 \\
\hline $\begin{array}{l}\text { WEATHER, EARTHQUAKE, } \\
\text { ETC. }\end{array}$ & 65 & $1.6 \%$ & 25 & $\begin{array}{l}\text { Falls from an } \\
\text { Elevation }\end{array}$ & 18 & $1.6 \%$ & 19 \\
\hline $\begin{array}{l}\text { MISJUDGMENT, HAZ. } \\
\text { SITUATION }\end{array}$ & 684 & $31.7 \%$ & 2 & Struck-By & 272 & $36.5 \%$ & 2 \\
\hline \multirow{2}{*}{$\begin{array}{l}\text { MALFUNC IN SECURING/ } \\
\text { WARNING OP }\end{array}$} & 224 & $5.7 \%$ & 15 & $\begin{array}{l}\text { Falls from an } \\
\text { Elevation }\end{array}$ & 37 & $3.3 \%$ & 17 \\
\hline & 10 & $6.0 \%$ & 14 & Respiratory Failure & 7 & $4.3 \%$ & 13 \\
\hline $\begin{array}{l}\text { DISTRACTING ACTIONS BY } \\
\text { OTHERS }\end{array}$ & 10 & $1.1 \%$ & 28 & $\begin{array}{l}\text { Caught In/ or } \\
\text { Between }\end{array}$ & 0 & $0.0 \%$ & 27 \\
\hline \multirow{2}{*}{$\begin{array}{l}\text { SAFETY DEVICES REMOVED/ } \\
\text { INOPER. }\end{array}$} & 465 & $11.8 \%$ & 8 & $\begin{array}{l}\text { Falls from an } \\
\text { Elevation }\end{array}$ & 149 & $13.4 \%$ & 4 \\
\hline & 33 & $13.0 \%$ & 5 & Struck-Against & 1 & $1.5 \%$ & 20 \\
\hline $\begin{array}{l}\text { INSUFF/LACK/ENGINEERNG } \\
\text { CONTROLS }\end{array}$ & 31 & $3.3 \%$ & 23 & $\begin{array}{l}\text { Caught In/ or } \\
\text { Between }\end{array}$ & 22 & $6.7 \%$ & 12 \\
\hline \multirow{2}{*}{$\begin{array}{l}\text { INSUF/LACK/PROTCV WRK } \\
\text { CLTHG/EQUIP }\end{array}$} & 218 & $5.5 \%$ & 17 & $\begin{array}{l}\text { Falls from an } \\
\text { Elevation }\end{array}$ & 108 & $9.7 \%$ & 10 \\
\hline & 10 & $4.0 \%$ & 19 & Struck-Against & 7 & $10.3 \%$ & 8 \\
\hline
\end{tabular}


These statistical results will assist safety managers to understand which risk factors they need to control first on a construction site in order to reduce the likelihood of fatalities. As shown in Table 6, 51.5\% of the fatal falling from an elevation can be addressed by controlling work surface and facility layout conditions. This risk factor is also responsible for 1,931 falling accidents that would highly impact on the improvement of safety management performance when controlled. If safety managers want to reduce fatal struck-by accidents, they can investigate related risk factors including catch point/puncture action, shear point action, flying object action, material handling equipment or method, illumination, and misjudgement of hazardous situation and determine which risk factor is most sensitive to the injury severity by considering the likelihood of fatal struck-by accidents resulted by each risk factor. In this example, misjudgement of hazardous situation accounted for $36.5 \%$ of the fatal struck-by accidents and materials handling equipment or method resulted in $16.1 \%$ of the accidents. Thus, safety managers may make a strategic safety management plan by strengthening daily toolbox talks to review preceding construction activities and related hazardous situations or by enforcing daily equipment inspection and casual operator training.

\section{Conclusions}

The study presented in this paper reviewed information on 9,358 accidents which occurred in the U.S. construction industry between 2002 and 2011, first identifying key risk factors associated with each accident type by analysing observation frequency of each environmental or human risk factor. The research then determined the significant risk factors which highly correlated to the injury severity and investigated the relationship among the different risk factors, accident types and injury severity through statistical analysis. The empirical analysis with the original accident information supported the research findings and the large number of accident samples supported reliable statistical analyses. The statistical analysis explained that construction managers' and safety managers' roles are critical to reducing human-related risks - such as misjudgement through safety training and education, sufficient supply and appropriate use of PPE and safety devices, and proper site safety inspection. However, for environment-related factors, the dominant risk factors were different depending on the different accident types and thus a statistical solution for risk identification and warning may be able to enhance the safety of working environments. The outcomes of this study will assist safety managers to understand the nature of construction accidents and plan for strategic risk mitigation. This can be achieved by prioritizing high frequency risk factors to effectively control accident occurrence and manage the likelihood of fatal injuries on construction sites when an accident is unavoidable.

Nevertheless, there are still limitations and future improvement opportunities. First, the combination ef- fects between the human-related factors and the environmental factors on accident types and injury severity need to be investigated since it is believed that a safer working environment can support safer decision making and behaviours of workers on construction sites and vice versa. The authors are currently working on this analysis. Second, the risk factors discussed in this paper only included environment-related and human-related factors determined by OSHA in their accident investigation reports. Since safety management is a more integrated process throughout the construction lifecycle, these factors need to be integrated with other organizational factors and safety culture for better planning of risk mitigation. To achieve this, industry participation should be engaged in the research, from the accident data collection process to the mitigation strategy development. Additionally, the research findings can be linked with onsite safety inspection processes for practical implementation of risk identification and mitigation. Safety performance measurement techniques can be incorporated to evaluate the practicality and the usefulness of the research findings.

\section{Acknowledgement}

This work is financially supported by Korea Ministry of Environment (MOE) as "Knowledge-based Environmental Service (Waste to Energy) Human Resource Development Project". The authors also acknowledged the research support provided by the Integrated Research Institute of Construction and Environmental Engineering (IRICEE) at Seoul National University.

\section{References}

Agresti, A. 1992. A survey of exact inference for contingency tables, Statistical Science 7(1): 131-153. http://dx.doi.org/10.1214/ss/1177011454

Center for Construction Research and Training. 2008. The construction chart book - The U.S. construction industry and its workers. MD: Silver Spring. 80 p.

Cheng, C. W.; Leu, S. S.; Lin, C. C.; Fan, C. 2010. Characteristic analysis of occupational accidents at small construction enterprises, Safety Science 48(6): 698-707. http://dx.doi.org/10.1016/j.ssci.2010.02.001

Chi, C. F.; Yang, C. C.; Chen, Z. L. 2009. In-depth accident analysis of electrical fatalities in the construction industry, International Journal of Industry Ergonomics 39(4): 635-644. http://dx.doi.org/10.1016/j.ergon.2007.12.003

Chi, C. F.; Chang, T. C.; Ting, H. I. 2005. Accident patterns and prevention measures for fatal occupational falls in the construction industry, Applied Ergonomics 36(4): 391-400. http://dx.doi.org/10.1016/j.apergo.2004.09.011

Fisher, R. A. 1954. Statistical methods for research workers. Edinburgh: Oliver and Boyd. 339 p.

Haslam, R. A.; Hide, S. A.; Gibb, A. G. F.; Gyi, D. E.; Pavitt, T.; Atkinson, S.; Duff, A. R. 2005. Contributing factors in construction accidents, Applied Ergonomics 36(4): 401-415. http://dx.doi.org/10.1016/j.apergo.2004.12.002

Heinrich, H. W. 1936. Industrial accident prevention. New York: McGraw-Hill. 450 p.

Heinrich, H. W.; Petersen, D.; Roos, N. 1980. Industrial accident prevention. $5^{\text {th }}$ edition. New York: McGraw-Hill. $468 \mathrm{p}$. 
Hinze, J.; Huang, X.; Terry, L. 2005. The nature of struck-by accidents, Journal of Construction Engineering and Management 131(2): 262-268.

http://dx.doi.org/10.1061/(ASCE)0733-9364(2005)131:2(262)

Hinze, J.; Pedersen, C.; Fredley, J. 1998. Identifying root causes of construction injuries, Journal of Construction Engineering and Management 124(1): 67-71.

http://dx.doi.org/10.1061/(ASCE)0733-9364(2003)129:3(262)

Huang, X.; Hinze, J. 2003. Analysis of construction worker fall accidents, Journal of Construction Engineering and Management 129(3): 262-271.

http://dx.doi.org/10.1061/(ASCE)0733-9364(2003)129:3(262)

Loosemore, M. 1999. The behavioural aftermath of accidents, in Proceedings of the CIB W55 \& W65 Joint Triennial Symposium, 5-10 September 1999, Cape Town, South Africa.

Mitropoulos, P.; Cupido, G.; Namboodiri, M. 2009. Cognitive approach to construction safety: task demand-capability model, Journal of Construction Engineering and Management 135(9): 881-889.

http://dx.doi.org/10.1061/(ASCE)CO.1943-7862.0000060

Occupational Health and Safety Administration (OSHA). 2002a. Inspection \#305449530. U.S. Department of Labor, Washington, DC.

Occupational Health and Safety Administration (OSHA). 2002b. Inspection \#302542667. U.S. Department of Labor, Washington, DC.

Occupational Health and Safety Administration (OSHA). 2002c. Inspection \#120165543. U.S. Department of Labor, Washington, DC.

Occupational Health and Safety Administration (OSHA). 2003a. Inspection \#300794534. U.S. Department of Labor, Washington, DC.

Occupational Health and Safety Administration (OSHA). 2003b. Inspection \#306137571. U.S. Department of Labor, Washington, DC.
Occupational Health and Safety Administration (OSHA). 2004. Inspection \#305354672. U.S. Department of Labor, Washington, DC.

Occupational Health and Safety Administration (OSHA). 2005. Inspection \#126182641. U.S. Department of Labor, Washington, DC.

Occupational Health and Safety Administration (OSHA). 2006. Inspection \#309572386. U.S. Department of Labor, Washington, DC.

Occupational Health and Safety Administration (OSHA). 2007. Inspection \#311336200. U.S. Department of Labor, Washington, DC.

Occupational Health and Safety Administration (OSHA). 2008. Inspection \#312508732. U.S. Department of Labor, Washington, DC.

Occupational Health and Safety Administration (OSHA). 2011. Inspection \#314574203. U.S. Department of Labor, Washington, DC.

Pearson, K. 1900. On the criterion that a given system of deviations from the probable in the case of a correlated system of variables is such that it can be reasonably supposed to have arisen from random sampling, Philosophical Magazine, Series 550(302): 157-175.

http://dx.doi.org/10.1080/14786440009463897

Sawacha, E.; Naoum, S.; Fong, D. 1999. Factors affecting safety performance on construction sites, International Journal of Project Management 17(5): 309-315. http://dx.doi.org/10.1016/S0263-7863(98)00042-8

Suraji, A.; Duff, A. R.; Peckitt, S. J. 2001. Development of causal model of construction accident causation, Journal of Construction Engineering and Management 127(4): $337-344$.

http://dx.doi.org/10.1061/(ASCE)0733-9364(2001)127:4(337)

Seokho CHI. An Assistant Professor at the Department of Civil and Environmental Engineering at Seoul National University in Seoul, Korea. He has worked on construction management, information technology (IT) applications in construction, Building Information Modelling (BIM), construction automation and process simulation, occupational health and safety in construction, and sustainable infrastructure management.

Sangwon HAN. An Assistant Professor at the Department of Architectural Engineering at the University of Seoul, Seoul, Korea. His research interests include construction productivity and safety improvement, computer simulation modelling, and information technology in construction.

Dae Young KIM. An Assistant Professor at the Department of Architectural Engineering at Dong-Eui University, Busan, Korea. His research interests focus on project success strategies for electrical construction management, decision support modelling for sustainable infrastructure management, pavement performance and maintenance management, workforce management for project development and construction engineering.

Yoonjung SHIN. A Graduate Student in the Construction Innovation Laboratory at the Department of Civil and Environmental Engineering at Seoul National University in Seoul, Korea. She has worked on Big-data, data-mining and Building Information Modelling (BIM). 